\title{
WILEY

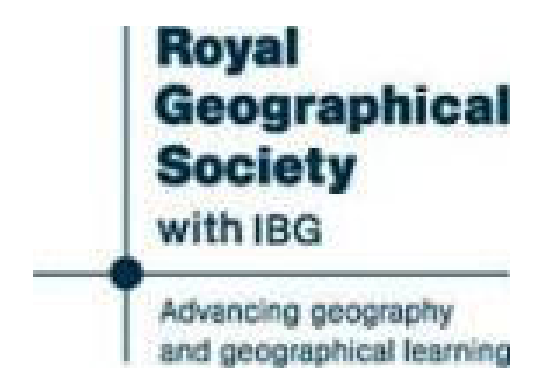

Journey to the Universities' Mission Station of Magila, on the Borders of the Usambara Country

Author(s): Alfred Bellville

Source: Proceedings of the Royal Geographical Society of London, Vol. 20, No. 1 (1875 - 1876), pp. 74-78

Published by: Wiley on behalf of The Royal Geographical Society (with the Institute of British

Geographers)

Stable URL: http://www.jstor.org/stable/1799895

Accessed: 12/06/2014 22:21

Your use of the JSTOR archive indicates your acceptance of the Terms \& Conditions of Use, available at

http://www.jstor.org/page/info/about/policies/terms.jsp

JSTOR is a not-for-profit service that helps scholars, researchers, and students discover, use, and build upon a wide range of content in a trusted digital archive. We use information technology and tools to increase productivity and facilitate new forms of scholarship. For more information about JSTOR, please contact support@ jstor.org. 
planted on the side of the hill, about 2 yards apart, with a small bank on the lower side to catch the rain-water and retain it round the plant.

Leaving Yanga in the morning, they proceeded on for nearly a mile in a westerly direction up the hill by a broad road, near the top turning off to the north-west, by a clove-lined road, to the house of Masingini at the top. This house, at an elevation of 390 feet above sea-level, is the residence of a sister of the Sultan; and occupying one of the highest spots in the island, commands a most extensive view from the sea at Chuaka, all round the south end of the island, up the west side to the north-west. The view is very fine. Dunga comes out in bold relief to the south-east, while Zanzibar and the ships are plainly seen to the south-west. From Masingini House, the party descended in a north-west direction, by long spurs and deep water-worn uncultivated ravines to the lowest cultivated undulating flats. It was evident by the deep-cut ravines that the chief force of the rainsqualls was expended on the western side of the ridge, as well as by the numerous small streams crossed later. The soil was chiefly red loam, showing in some places quantities of a red gravel underneath. After descending about 250 feet, they crossed the regular cultivated country common to that part of Zanzibar, and struck the main road to Kotlotoni at the sea, just south of Boolooboo. As their time was now up, they returned to the Mission House, at Kiungani, by the road that led through the Malagash suburb of Zanzibar, halting for a short time to see the new and well-built houses of Chumah and Susi, situated in that suburb of Zanzibar, at no great distance from the house inhabited by Dr. Livingstone when he was last in Zanzibar. The party arrived at the Mission House in the evening, after an absence of 8 days.

With regard to the population of the island, all the part immediately south and north of Zanzihar is most densely populated. A hundred to the square mile could not be too much-very likely it is under the mark. Uzi would have at least 2000 inhabitants; while the smaller villages, such as Bweyu, Paji, Mayoni, and a few others, 1000 each, and the smaller ones 500. One great thing noticeable was the absence of mosquitoes. None of the party had any occasion to use their mosquito nets at any place on the march, while at Kiungani they are anything but absent. A few bearings by prismatic compass were taken, which are shown on our map.* The outline of the island and general features are from the Shearwater's survey, corrected where discrepancies appeared. The whole island being so flat, as a rule, with no distinguishing points, it was impossible to get more than one or two bearings here and there, more as a general guide than to fix any position.

\section{Journey to the Universities' Mission Station of Magila, on the Borders of the Usambara Country. By Alfred Bellville, F.R.G.S.}

ON the 7th of July, 1875, a party, consisting of the Right Rev. Bishop Steere, Rev. J. P. Farler, Messrs. Beardall, Moss, and the writer, together with several of the mission boys and Chumah and Susi, and a native crew, started in the yawl Ware, from the Mission-house at Kiungani, for the River Mtangata, half-way between Pangani and Tonga. Besides the above party, we had in the boat about 2 tons of baggage and stores. We left about 4 P.M., and after about five hours' sailing, with a fresh breeze well off the land from the eastward, anchored off Osawemba Point in 15 fathoms water, with good muddy

* Deposited in the Map-Room of the Society.-[ED.] 
bottom. Leaving here at daylight, with a fair wind, we arrived off Pangani about noon; and passing inside the reefs, under the skilful steering of an old master of a dhow, to the north of Maziwi Island, we arrived off the mouth of the Mtangata River about 2.30 P.M., at low water. At first a long spit of sand seemed to bar all entrance, but on sailing further to the north the wide river opened, and after an unsuccessful attempt to beat up, we finally pulled to the town of Marongo, situated on the south shore of the harbour, about half a mile from the sea. The mouth of the river, together with two islands - Yambi to the north, and Karange to the south - forms a good harbour. Completely shut in to the southward by reefs and islands, the dhows can safely lie there during the south-west monsoon; and as the only opening to the north-east is by the narrow passage between the two islands, the harbour must be comparatively sheltered at all seasons. Opposite the village of Marongo there is from 1 to $1 \frac{3}{4}$ fathom at low-water springs, and all sand and mud, with no rocks; further out the water deepens to 3 and more fathoms. At Marongo a two-storied house, situated near the beach, in the joint possession of the Mission and one of the chiefs, forms a good mark for entering the harbour. The village is half surrounded by a loopholed low wall; but as two chiefs and parties claim possession of it, and they are always at loggerheads - though not openly at war - the wall was never finished, the other party refusing to contribute their half or allow it to be done. From Marongo we took a westerly course, the evening of the day after we arrived, and skirting the harbour, crossed the river-about balf a mile wide-that comes from the south-west. On the Marongo side is the village of Pambani, on the other that of Tongoni, near which are the ruins visited by Captain Burton. We also visited them on our return.

On the following morning we mustered our porters-about 20-and left Tongoni, proceeding in a general westerly direction, about 7 A.M., crossing a mangrove-lined salt creek at the back of the village; and then ascending a rise, in which the coral rock showed plainly, passing through many fields of mtama (Holcus sorghum), and then into the open, well-wooded country beyond. When once you leave the shore, you leave all signs of life. We stopped at the edge of the belt of cultivation to adjust the burdens, and then marched on, halting at a hollow called Kwamkembe, about 9 A.M., where there had once been a village, and water was still found. The country was very flat, being, by aneroid, at a general elevation of 106 feet above sealevel. From this place we proceeded on in a w.N.w. direction, passing through a thick wood of small trees and undergrowth. After leaving here the country became more undulating and the trees thinner, and it assumed a more parklike appearance-very like Natal in the first fifteen miles from the sea. The soil was red loam on the hills and black in the valleys, and appeared eminently suited for sugar and coffee; water, though not on the surface, was to be had by digging a few feet. About noon we passed a large baobab tree, on which was the Rev. C. Alington's name; and a few miles beyond was a well dug by the same gentleman. Here we rested, and enjoyed a slight repast. The hills over which we had come were about an average elevation of 200 feet. No habitations of any kind, or any sign of cultivation, were to be seen, so utterly deserted both by man and beast is this tract of country. Starting again, and proceeding in a w.N.w. direction still, we crossed a similar country, and arrived at the bottom of a steep hill crowned with coconut-palms, which as yet had been absent from the country. On ascending the hill we arrived at a dense wood in which was situated the first village, called Yamba. Passing on in a north-east direction through the wood, we arrived at the top of the rise at the village of Umba, having done about 20 miles, or about 17 as the crow flies, pretty well tired after our first day's march. Here we stayed for that night. The village lay inside the wood, apparently surrounded by 
four stockades, with coconut-palms growing plentifully among the huts, which were of an oblong shape with the corners rounded off, built of sticks and mud, with a thatch coming nearly to the ground. The elevation of the village was about 500 feet, and the hill was the first regular ridge from the sea. Leaving Umba in the morning about 7 A.M., we descended about 200 feet into a hollow on the other side of the hill, and in the first mile, making a southwesterly course, we crossed a small stream three times, which apparently ran to the south-west. The country was well cultivated here-mtama, mahindi, mbualzi, and sugar-cane being grown in patches. Further on we skirted a dense wood, in which were many stockaded villages. Near one of these we were shown a hollow where, for native wars, a most bloody engagement took place between the natives of the country and the Wadigo, a northern neighbouring tribe, in which all the latter were ultimately surrounded and killed; otherwise native wars are very poor affairs, about 10 men being killed in a year's fighting. After passing many villages, we at last mounted another ridge about 100 feet higher than the first, and found ourselves at the village of Nebué, where we halted. We had walked about 6 miles. From here you could see across an undulating country, lower than the ridge, yet not flat; and beyond that, the spur of the mountain behind which Magila was situated. After a short rest, we proceeded on in a w.s.w. direction, turning, after we had walked some distance, in a more westerly direction, passing over hills and through a well-cultivated country, till we came to a small stream about 15 yards wide, and knee-deep, running in a N.N.E. direction, of which the banks were thickly wooded, which we were afterwards informed ran to Tanga. The bed of the river had an elevation of about 450 feet above the sea. After crossing this river we passed through a flat, marshy country, where large quantities of rice were grown, and then ascended the spur before mentioned, which ran nearly north and south-the sonthern being the low end, while the northern formed two small and thickly-wooded peaks-after which it joined the general mass of the mountain. Crossing this spur, we turned round to the north, walking in a N.N.w. direction, crossing several very steep hills (spurs of the larger one), and meeting our old friend the river, here running about sonth-east; then finally ascending a small hill, at the foot of which ran the river, we found ourselves at the Universities' Mission Station of Magila, at an elevation of about 120 feet above the surrounding country, and 600 jeet above the sea; under the shadow of a lofty wooded mountain, and surrounded by a wooded and hilly country, that looked in the distance as if covered with onedense forest. The Station possessed a large house, built of poles and mud in the native fashion, but large and roomy, containing 6 good-sized rooms, covered with an ample thatch, whose extensive eaves formed a large verandah; standing on a platform of granite blocks (which stone abounded in the neighbourhood), chiefly of a grey and a reddish hue. Also several smaller huts, an iron chapel and school-room, and a well-built cow- and hen-house stocked with a plentiful supply of firewood. An avenue of bananas and other fruit trees led up the hill from the river on the one side, while the other was so steep that it took the greatest amount of care in walking to keep one from slipping down the whole distance, especially as the soil was a stiff red clay:

During our stay at Magila I obtained the latitude by a meridian altitude of the sun, which gave it as $5^{\circ} 6^{\prime} \mathrm{s}$; ; as I had not much time, I did nothing for longitude, being dependent on the dead reckoning and bearings chiefly for distance. We also ascended the nearest peak to the station, walking up a most beautiful gully between the mountains by the side of a roaring torrent that formed one of the head-waters of the small river before mentioned, which formed rapids and cascades leaping over the rocks of granite, of which the mountain was composed. Some of the trees were very lofty, over 100 feet 
without a branch and above 6 feet in diameter; the natives call them "mvale." After ascending a good distance, the path left the gully, and passed through a small village, many of which are on the mountains, and some fields of mahindi, and then became very steep, and finally reached the top at a neck joining two peaks. The first one was about 1600 feet above the sea, and 1000 above Magila ; the other was 2080 feet above sea-level. 'The view from the top was splendid; the whole country was spread out before you like a map, throughout nearly three-quarters of the circle from Waseen to west of Tougwe Mountain. In general the country appeared flat, while the hidden quarter was filled up by the dark masses of the Kombora Range, the principal peak of which was hidden. We could not see Pemba, though we heard guns fired at.Zanzibar on the arrival of the Admiral. The highest peak of this mountain mass I estimated at 3000 feet. The mountain is chiefly granite, though I found sandstone of a dark-red colour and a very hard freestone on the northern side. Whilst we were at Magila we were visited by many of the surrounding people, and I made inquiries as to the existence and size of Lake Manyara. I was told that there was such a lake; that it was very large; and a man told me that its waters ran into the Rufu, or river of Pangani. The great thing at Magila is trading with the Masai, or M'sai, as the people pronounce it. We leit Magila, after remaining there four days, and marched to Umba the first day, remaining there that night, and starting early the next morning we reached Marongo by sunset; here we remained two days, as it was Friday when we arrived there. We were told that two dhows had left with 150 slaves, the night before we arrived, for Pemba; also several small, suspicious-looking dhows came and went away during our stay, always in the night. We left on Sunday evening, and made a futile attempt to beat down the coast to Zanzibar; so after spending a night and half a day in an open boat in most tremendous showers of rain, we returned to Marongo; and two days after, when the rain abated a little, set out to walk to Pangani. We left Marongo in the morning early, and walked along the beach for about five miles, then turned inland to avoid some rocks, and, a shower coming on, we halted at a village where the people told Chumah that a gang of slaves had passed that morning further inland on their way to Marongo, going inland on purpose to avoid us, from Kilwa. After passing through a flat district, where we walked in water, we again struck the beach, and crossed a small river about nine miles from Marongo, which the natives call half-way. Here the footmarks of the slaves were plainly visible, as the sand was very soft and loose, which made walking very tedious. After leaving the river, a mile further on, we entered a mangrove forest which extended a long way into the water, leaving a narrow path between the sea and the bush on the shore, which was strewed with wreckage of all descriptions; pieces of kitandas or native bedsteads, dhow planks, figure-heads, masts of ships and boats. This forest was about three miles long. After leaving this, we finally left the beach, and took a path across the country, and after walking about four miles, we found ourselves on the shores of Pangani Bay, about a mile from the town. We passed through a large plantation of coconut-palms, chiefly grown for " tembo," or the palm wine, and arrived at the town; where the Governor-a pompous old Arab, who treated us with scant courtesy, and gave himself more airs than the Sultan himself-after he had said his afternoon prayers, received us in a very dirty house, gave us sherbet which actually tasted nice and seemed refreshing, though it appeared to be the same as usual ; but we were tired and dusty. He then dismissed us, and we retired to a Banyan's house, where we heard that a dhow belonging to the Customs' people was leaving that night for Zanzibar, so we took our passages, and reached Zanzibar early the next morning. We had been away altogether two weeks and two days. 
If it is ever intended to establish a settlement on the coast to prevent the slaves marching north, the country between Magila and the coast is admirably fitted for it by natural position and present circumstances. There is a good harbour; communication opened up with the interior; and a fertile tract of splendid sugar and coffee land, with no one to dispute the ownership, only waiting for some one to come and take possession ; and in winter, at all events, it is not unhealthy, and free from mosquitoes.

\section{On a proposed Trade Route from the Gambia to Timbuctoo. By H. T. M. COOPER, Administrator of the Gambia.}

\section{Government House, Bathurst, River Gambia,} September 15th, 1875 .

HAVING seen a project on foot, the object being the opening up the resources of Central Africa, as likewise the lessening of the slave trade, and as it appears to me a vast undertaking, I therefore beg to offer a few remarks, and at the same time to enclose a chart* of a route which I consider easy and practicable for traders, and which only requires an expedition to be started to show the benefits which may be derived therefrom. I have taken great pains in drawing up the course, and have gleaned the principal knowledge, outside my own personal experience, from Arabs and a man from Timbuctoo, and a native of Humdallahi, and who is perfectly trustworthy. I am confident that the reported richness of the country, and our opening up an intercourse with the natives in the far regions in the neighbourhood of the Sabara desert, would amply repay us for our trouble, besides be the making of this settlement, one feature of which is its noble river.

You will perceive by the chart, that from Bathurst water-traffic can be had as far as Fattatenda, which is distant from St. Mary's Island about 280 miles. On reaching that place the traveller starts for Medina, King Jarrta of Woolie's town (our ally); from thence to Senoudebou, the capital of Bundoo, King Barcery Sarda, a great friend of ours, and who is decorated with the Legion of Honour; thence on to Kasso Madina, the country of King Samballa, who is the father-in-law of the King of Bundoo, and also our friend. From Kasso you journey to Jambourk, where his territory ceases; and you are now within the territory of Amadoa, King of Segou (son of the late Alaroi Maroo). From Jambourk you leave for Guematourou, and from thence to Macora; then on to Yamina, where there is a powerful chief, who is under the rule of the King, who resides at the next town, on the banks of the Niger, called Segou Sikoro. The extent of this King's territory ceases at his town.

At Yamina boats can be had, or long trade canoes. After leaving Segot Sikoro the traveller is in the Arab country, called the Macini country. The King's name is "Abbadde," and he lives at his capital, called Humdallahi, which is on the right bank of the Niger. From thence you proceed towards the Lake Debou, and here the above King's power ceases. Crossing the lake you come into the territory of the Foulahs, whose King's name is Alionde. The large town on the banks of the lake is called Mrawoona. The King resides at a place called "Chuke," some distance from the former. You then proceed upwards, until you reach a town called Bourgbare; here the Foulah King's power ceases, and you are in the territory of the chief of the

* Deposited in the Map-room of the Scciety.-[Ev. $]$ 